ISBN 978-93-5137-179-3

\title{
A case study of jalaukavacharan in management of non healing diabetic ulcer
}

\author{
Gaurav.R.Gupta*1, Shubhangi Badole ${ }^{2}$, Sanjiv Yadav ${ }^{3}$
}

1. M.S Scholar Shalyatantra Department (Samanya shalya),

2. Asso. Professor Shalya-Tantra Department,

3. Professor H.O.D Shalya-Tantra Department \& Dean,

Dr. G. D. Pol Foundation’s Y.M.T Ayurvedic Medical College \& Hospital,

$$
\text { P.G Institute Kharghar, Navi Mumbai. }
$$

*Corresponding author: gauravgupta20366@gmail.com

\section{Abstract:}

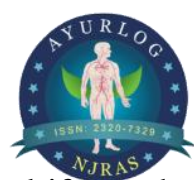

Diabetes mellitus is known for its multifaceted complication with neuropathy \& subsequent diabetic wounds frequently The prevalence of foot ulcer ranges from $4 \%$ to $10 \%$ among persons diagnosed with diabetes mellitus. These ulcer frequently become infected and need hospitalization. The basic reason of ulceration are infection and cause progressive tissue necrosis with poor wound healing in presence of ischemia. A healthy wound in a normal body heals earlier with a minimum scar as compared to a non-healing diabetic ulcer. In order to overcome or diminish the consequence's a common treatment must be implemented.

Therefore in the present concept, all efforts are directed to keep the wound clean during the various stages of its healing. The need for cost effective, easy to handle, available to all hands modality in the management of such wound is necessary. Acharaya sushrut explains vrana as a condition in which there is discolouration and need for the regeneration of damaged tissue in the 8 explained vrana vastu. Vrana is described in sushrut samhita, sutrastahan and chikitsasthan with 60 treatment modalities explained in shashti upakram, ghrit. Ghrit application is one of the 60 explained modalities.

KEYWORD: Non healing diabetic ulcer, jalaukavacharan, Diabetes mellitus 


\section{INTRODUTION:}

Diabetes mellitus is known for its multifaceted complication with neuropathy $\&$ subsequent diabetic wounds frequently The prevalence of foot ulcer ranges from $4 \%$ to $10 \%$ among persons diagnosed with diabetes mellitus. These ulcer frequently become infected and need hospitalization. The basic reason of ulceration are infection and cause progressive tissue necrosis with poor wound healing in presence of ischemia. A healthy wound in a normal body heals earlier with a minimum scar as compared to a nonhealing diabetic ulcer. In order overcome or diminish the consequence's common treatment must be implemented.

Therefore in the present concept, all efforts are directed to keep the wound clean during the various stages of its healing. The need for cost effective, easy to handle, available to all hands modality in the management of such wound is neccessary. Acharaya sushrut explains vrana as a condition in which there is discolouration and need for the regeneration of damaged tissue in the 8 explained vrana vastu. Vrana is described in sushrut samhita, sutrastahan and chikitsasthan with 60 treatment modalities explained in shashti upakram, ghrit. Ghrit application is one of the 60 explained modalities.

Jalaukavacharan has property of vrana ropan krumighna, puyanashak, kandu nashak and release herudin which is instant medication which help to increase wound healing. Use of the traditional management in such conditions may help in avoiding surgical procedures, which is a key factor for patients of low socioeconomic status.

\section{CASE STUDY:-}

A patient 45 year old male patient, k/c/o iabetes mellitus since 6yrs visited the Q.P.D with the complaint of a non-healing wound on right limb (shin bone region) just above ankle, since 2 months. The patient had history of Agantuj hetu ( accidental trauma) and was undergoing treatment under local medical practitioner and daily dressing for almost 2 months. Patient consulted a renowned surgeon of other hospital and was suggested debridement followed by skin grafting. Since the patient wanted to recover without any surgical intervention and hence was willing for the open trial study.

P/M/H:- $\quad \mathrm{K} / \mathrm{C} / \mathrm{O}$ diabetes mellitus since 6yrs, no h/o hypertension, Kochs or any 
other systemic disease. Present medication tab. GMP 2, Dose 1 O.D

P/S/H: No any surgical history

H/O ADDICTION: addiction to alcohol for more than 12 years, no other addiction.

H/O DRUG ALLERGY: No history of allergy to any specific drug.

\section{General Examination:}

Pulse - 80/min, B.P: 130/80 $\mathrm{mm}$ of $\mathrm{Hg}$, Afebrile, general condition: Fair

\section{LOCAL EXAMINATION:}

INSPECTION: Infected wound just above the right ankle at shin bone region with

active foul smelling pus discharge with no active bleeding.

PALPATION: mild tenderness, with discharge on pressure.

\section{INVESTIGATION:}

Blood sugar (fasting \& post prandial) fasting $134 \mathrm{mg} / \mathrm{dl}$, post prandial $188 \mathrm{mg} / \mathrm{dl}$.

C.B.C report showing raised level of W.B.C level \& ESR. Culture sensitivity of OBSERVATION: the pus sample collected from the wound swab which did not show any specific changes or resistance to any anti-biotic. Serum creatine: within normal limits.

\section{AIM:}

ASSESSMENT OF MANAGEMENT OF NON HEALING DIABETIC ULCER MANAGEMENT

\section{TYPE OF STUDY:}

Interventional open single case study

\section{MATERIAL \& METHOD:}

MATERIAL: Jalukavacharan for local application

METHODS: jalukavacharan was used as local application on wound for two month. The wound was first daily cleaned with normal saline and the jaluka was applied covered with sterile gauze piece.

\section{MEDICATION:}

1. Tab. Gmp 2 one O.D

2. Tab. Enzoflam s.o.s

3. Inj. Amikacin $1 \mathrm{gm}$ intramuscular for 5 days.

\begin{tabular}{|l|l|l|l|l|l|l|l|l|l|}
\hline SYMPTOMS & DAY 1 & DAY 7 & $\begin{array}{l}\text { DAY } \\
15\end{array}$ & $\begin{array}{l}\text { DAY } \\
22\end{array}$ & $\begin{array}{l}\text { DAY } \\
30\end{array}$ & $\begin{array}{l}\text { DAY } \\
37\end{array}$ & $\begin{array}{l}\text { DAY } \\
45\end{array}$ & $\begin{array}{l}\text { DAY } \\
52\end{array}$ & $\begin{array}{l}\text { DAY } \\
60\end{array}$ \\
\hline SIZE OF & $10 \mathrm{~cm} \times 4$ & $9.5 \times 3$. & $9.2 \times 3$. & $8.4 \times 3$. & $8.2 \times 3$ & $7.3 \times 2$ & $6.4 \times 2$ & $5.1 \times 1$ & $4.2 \times 0$ \\
WOUND & $\mathrm{cm}$ & 8 & 6 & 3 & .1 & .6 & .1 & .6 & .8 \\
\hline
\end{tabular}




\begin{tabular}{|l|l|l|l|l|l|l|l|l|l|}
\hline $\begin{array}{l}\text { GRANULAT } \\
\text { ION }\end{array}$ & $\begin{array}{l}\text { Slough } \\
\text { yellowis } \\
\mathrm{h}\end{array}$ & $\begin{array}{l}\text { Slough } \\
\text { yellow } \\
\text { ish }\end{array}$ & $\begin{array}{l}\text { yellow } \\
\text { ish }\end{array}$ & $\begin{array}{l}\text { Mild } \\
\text { yellow } \\
\text { ish }\end{array}$ & $\begin{array}{l}\text { pinki } \\
\text { sh }\end{array}$ & $\begin{array}{l}\text { pinki } \\
\text { sh }\end{array}$ & $\begin{array}{l}\text { Dark } \\
\text { pinki } \\
\text { sh }\end{array}$ & red & red \\
\hline $\begin{array}{l}\text { DISCHARG } \\
\text { E }\end{array}$ & $\begin{array}{l}\text { Foul } \\
\text { smell }\end{array}$ & $\begin{array}{l}\text { Mild } \\
\text { foul } \\
\text { smell }\end{array}$ & $\begin{array}{l}\text { Mild } \\
\text { foul } \\
\text { smell }\end{array}$ & $\begin{array}{l}\text { No } \\
\text { smell }\end{array}$ & $\begin{array}{l}\text { No } \\
\text { smell }\end{array}$ & $\begin{array}{l}\text { No } \\
\text { smell }\end{array}$ & $\begin{array}{l}\text { No } \\
\text { smell }\end{array}$ & $\begin{array}{l}\text { No } \\
\text { smell }\end{array}$ & $\begin{array}{l}\text { No } \\
\text { smell }\end{array}$ \\
\hline
\end{tabular}

The application of jalaukavachran in the trail showed successful results. From the observation

table it is clear that there were positive changes in size, granulation tissue, discharge.

\section{DISCUSSION:}

According to ayurvedic literature explained by acharya susruta The treatment for prmehjanya vran jalukavacharan keeps the wound margins soft, avoids fibrosis of wound edges leading to development of healthy and soft skin.

\section{RESULT:}

At the end of the 60 day trail the jalukavachran application showed remarkable results. Wound healed approximately by $45 \%$ in size with no discharge from the 15th day and healthy granulation tissue. The patient was satisfied as the surgical procedures advised were avoided.

\section{References:}

1. Agnivesha, Charaka, Dridhabala, Charak samhita, edited by $\mathrm{Vd}$. Yadhavaji Trikamaji Acharya, Chaukhamba Surabharati Prakshana, Varanasi, 2008

2. Sushrut samhita, edited by Dr. Anantram Sharma, Chaukhamba Surbharti Prakashan, Varanasi, 2013.

\section{Cite this article:}

A case study of jalaukavacharan in management of non healing diabetic ulcer Gaurav.R.Gupta, Shubhangi Badole, Sanjiv Yadav Ayurlog: National Journal of Research in Ayurved Science-2018; 6(2): 1-4 